\title{
POETIC IDIOSTYLE OF ERICH KÄSTNER
}

\section{Bandurko Z. V.}

\section{INTRODUCTION}

German literature has a lot of well-known movements and names, both in prose, and in poetry. One of them is the German-language lyrical-poetical discourse of the "New Objectivity" or "Neue Sachlichkeit", one of the leading movements of the cultural life in the Weimar Republic. The "New Objectivity" we define as a stylistic movement at the time of the Weimar Republic, which occupies the time period from 1924 to 1933. Its prominent representatives in the field of literature are M. Kaleko, E. Kästner (Kr.), J. Ringelnatz and others.

This literary movement the "New Objectivity" is characterized by the aesthetic features such as the focus on objective reality, pragmatism, factuality, documentary style, realistic themes and everyday language, which as a whole determine its acceptability as the object for linguistic and pragmatic analysis. The main techniques are: documentary style, report style, reportage, editing and precision. The attraction of non-literary spheres (for example, everyday and entertainment culture) and the media nature of literature (in the sense of integrating modern media, primarily cinema) are considered as common features of writing of the "New Objectivity"1. The purpose of the literature of this movement is "theoretically exact, wellfounded representation of facts" ${ }^{2}$. In addition, the representation of the reality of the Weimar Republic, the daily world and the concerns of ordinary people is achieved through everyday speech, which is easy to understand for all readers: "documentation instead of fiction, reportage instead of a novel these were $\langle\ldots\rangle$ the main program and aesthetic principles of the literary "New Objectivity"", . All this is necessary for our investigation.

${ }^{1}$ See a review in: Бандурко 3. Лінгвопрагматичні властивості німецькомовного лірико-поетичного дискурсу «Нової діловитості» : дис. ... канд філол. наук: 10.02.04. Херсон, 2019. $325 \mathrm{c}$.

${ }^{2}$ Pankau J. Einführung in die Literatur der Neuen Sachlichkeit. Darmstadt : Wissenschaftliche Buchgesellsaft, 2010. 144 S.

${ }^{3}$ Mörchen H. Vorkriegszeit, Pubertät und Krieg in deutscher Provinz. Ernst Glaesers "Jahrgang 1902" als Roman wider Willen. Neue Sachlichkeit im Roman: neue Interpretationen zum Roman der Weimarer Republik / hrsg. von S. Becker und C. Weiss. Stuttgart, Weimar : Metzler, 1995. S. 112-118. 
"New Objectivity" applies to all fields of literature. New literary forms and genres appear within the movement, including "useful lyrics" ("Gebrauchslyrik"). The latter we understand as a genre of lyrics, which poetic texts reproduce topical themes and issues; are written in a clear, accessible language, not burdened with heavy or significant artistic means; created with a variety of basic ideas, thematic content and structure; made in different genres, intended for any reader; are suitable for practical, reasonable and useful usage in everyday life; are composed with predominance of content over form, but with artistic expressiveness and aesthetic value.

At the same time, we consider the poetry of the "New Objectivity" as a part of the lyrical-poetical discourse, a subtype of artistic discourse. We define the lyrical-poetical discourse as a variety of speech-mental-communicative activity of the perception and the artistic representation of reality or the creation and artistic expression of the fictional reality as the whole world or some of its elements in a certain unity; a combination of linguistic creativity and communication of the author of the poetic text with its reader (the addresser with the addressee) that models cultural and linguistic universe of a certain age on the basis of the action of the poetic function of language, created by the usage of the different linguistic and stylistic means.

Thereafter, the lyrical-poetical discourse is a type of situational communication of a special kind, which is realized due to aesthetically marked language signs in a fascinate text that is integral in terms of structure and functioning.

The lyrical-poetical discourse of the "New Objectivity" models the cultural and linguistic universe of the Weimar Republic. The lyrical-poetical discourse of each representative of the "New Objectivity" we consider as a part of the lyrical-poetical discourse of the "New Objectivity".

The aim of the paper is to describe linguistic and pragmatic features of the idiostyle of Erich Kästner.

The object of the scientific research is the idiostyle of Erich Kästner.

The subject - linguistic and pragmatic features of the idiostyle of Erich Kästner.

The material of the investigation is presented by the poetic texts of Erich Kästner in the total amount of 330 poetic texts.

The methodology of the article is based on the pragmapoetics, a linguistic branch, developing on the basis of integration of linguopragmatics and linguopoetics.

\section{The main features of Erich Kästner's poetry}

In this paper we describe some features of Erich Kästner's idiostyle. In idiostyle and in the lyrical-poetical discourse of each author we can find the representation of the author's worldview, personified in language signs and personal manner of writing, which carries perlocutionary effect on the reader. 
The term idiostyle is defined as "a set of deep mechanisms for creating a text space by a certain author, distinguishing him from others. In a narrower sense, idiostyle is concerned with a system of linguistic and stylistic means, typical for the creative manner of a certain language personality" ${ }^{\prime 4}$. At the same time, idiostyle is a combination of characteristic features in the vocabulary, sentence construction, their correlation with each other, the use of metaphors, comparisons, various speech features, or a conscious avoidance of all of these ${ }^{5}$.

We should note that Erich Kästner is an unsurpassed master of words and his poetic texts are characterized by fun and cheerfulness, humour and satire, are full of philosophy and aphorisms, as well as biographical features. Each poetic text, selected for analysis in our research, illustrates not only leading aesthetic characteristics of the movement, but also the communicative processes of the lyrical-poetical discourse of the "New Objectivity", embodies the author's intentions, represents the illocutionary types of speech acts and can be considered from the point of view of linguopragmatic theories.

According to the scientists, E. Kästner's poetic texts tell "about life in a modern big city, about unemployment and political indifference, about the disillusionment of evil youth and about the helplessness of the individual in the midst of political and economic hardship" "with the humour, gaiety and cheerfulness, that reflects the aesthetic features of the movement the "New Objectivity".

Among other things, E. Kästner's poetic texts are biographical, because of certain statements and poetic texts $(0,30 \%)$, which lead the reader to believe that the author is talking about events from his own life, particularly the titles of poetic texts. But in such cases we should not forget about the fictionality and lyrical "I" of the poet, like in the poetic texts "Kurzgefasster Lebenslauf" and "Sergeant Waurich", for instance:

Die Schule, wo ich viel vergessen habe,

bestritt seitdem den grössten Teil der Zeit.

Ich war ein patentierter Musterknabe.

Wie kam das bloss? Es tut mir jetzt noch leid.

Dann gab es Weltkrieg, statt der grossen Ferien.

Ich trieb es mit der Fussartillerie.

Dem Globus lief das Blut aus den Arterien.

Ich lebte weiter. Fragen Sie nicht, wie (Kr., "Kurzgefasster Lebenslauf”).

${ }^{4}$ Юріна Ю. Ідіостиль Олени Теліги : дис. ... канд. філол. наук: 10.02.01. Херсон, 2016. 194 c.

${ }^{5}$ Парандовский Я. Алхимия слова. Петрарка. Король жизни / сост. и вступ. ст. С. Бэлзы. Пер. с польского. Москва : Правда, 1990. 656 с.

${ }^{6}$ Glaser H. Kleine Kulturgeschichte Deutschlands im 20. Jahrhundert. München : Beck, 2002.398 S. 
In addition, sometimes E. Kästner uses his first or last name to refer to himself, personify or separate himself from the lyrical hero, to create the impression that the narrative is conducted in the third person, for example:

Er sah mich ganz entsetzt die Hände falten

und sagte freundlich: "Kästner, wissen Sie,

warum die Tiere ihre Schnauze halten?"

Ich schwieg. Und war verlegen wie noch nie (Kr., "Ein Hund hält Reden").

We also meet poetic texts, written by E. Kästneras if for himself, which convey "communication" with himself, so called "self-communication" like in the poetic texts "Sich selbst zum 40. Geburtstag", "Unsanftes Selbstgespräch", "Paralytisches Selbstgespräch", e.g.:

Dreh dir den Kopf ab, falls du einen hast!

Auch ohne Kopf wirst du kein deutscher Denker.

Knüpf dich dezent an einen Lindenast.

Seit Zeile 5 wirst du davon nich kränker $<\ldots>$

(Kr., "Paralytisches Selbstgespräch").

At the same time, one of the main features of E. Kästner's lyrical-poetical discourse are irony and satire. In particular, the title of the poetry collection "Doktor E. Kästners Lyrische Hausapotheke" conveys "the idea that literature as a poetically fixed soul culture could have quite practical use", because "words manifest a magical power that not only moves us forward intellectually, but also affects us in many ways in the depth of our soul".".

We believe that E. Kästner's lyrical-poetical discourse is also characterized by aphorisms and his miniatures are a vivid manifestation of this, like "Das Verhängnis", "Die Grenzen des Millionärs", "Zusammenhänge", "Der Gegenwart ins Gästebuch", "Der Streber", "Moderne Kunstausstellung", "Aucheine Auskunft", "Für Stammbuch und Stammtisch" and many others, for instance:

Ein Mann, von dem ich wissen wollte, warum die Menschen einander betrügen, sprach: "Wenn ich die Wahrheit sagen sollte, müßt ich lügen" (Kr., "Auch eine Auskunft").

Freunde, nur Mut!

Lächelt und sprecht:

"Die Menschen sind gut,

bloß die Leute sind schlecht" (Kr., "Für Stammbuch und Stammtisch").

${ }^{7}$ Gerk A. Lesen als Medizin. Die wundersame Wirkung der Literatur. Berlin : Rogner \& Bernhard, 2015. 317 S. (E-Book).

${ }^{8}$ Ibid. 
The distribution of ideas and themes in E. Kästner's poetic texts shows that poetic texts are mostly civil (50\%) and philosophical $(39,09 \%)$ lyrics, but although landscape $(5,46 \%)$ and urban lyrics $(4,24 \%)$.

\section{Rhythmical and compositional structure of Erich Kästner's poetic texts}

It should be pointed out that the rhythmical and compositional structure of E. Kästner's lyrical-poetical discourse demonstrates expressiveness and variety.

Types of composition and compositional techniques make up 39,70\% of the total number of poetic texts, although the author's poetic texts are written mostly without their usage $(60,30 \%)$. So, the composition of a certain poetic text is determined mainly by the features of the strophic structure. By the way, frequently is also a combination of various types of composition and compositional techniques within one poetic text $(16,06 \%)$. However, the most frequent among their varieties are anaphoric composition $(8,79 \%)$, refrain $(6,36 \%)$, ring of the poetic text $(5,15 \%)$ and compositional epiphora $(1,82 \%)$.

In addition, the poetic text "Das Spielzeuglied" is a combination of two separate poetic texts, united by the same title. The poetic text "Die Maulwürfe oder Euer Wille geschehe" consists of three separate poetic texts. Some poetic texts are written in the form of a dialog, like "Belauschte Allegorie" and "Als die Synagogen brannten".

In E. Kästner's poetic texts we find also a displaced ring of the poetic text, in which repeated elements combine the first and penultimate verses, for instance, poetic texts "Kopernikanische Charaktere gesucht", "Prima Wetter", etc. An example is also the poetic text "Fachmännische Konsequenz", where the ring of the poetic text is formed by two winged Latin sayings, the second of which is a negative answer to the first question:

Cogito, ergo sum?

Mag sein! Doch die meisten sind dumm!

Drum

lautet des Fachmanns Befund:

Non cogitant, ergo non sunt! (Kr., "Fachmännische Konsequenz").

At the same time, the stanza ring has mostly single cases, as in E. Kästner's poetic text "Chor der Fräuleins":

Wir hämmern auf die Schreibmaschinen.

Das ist genau, als spielten wir Klavier.

Wer Geld besitzt, braucht keines zu verdienen.

Wir haben keins. Drum hämmern wir (Kr., "Chor der Fräuleins"). 
The refrain can be a separate sentence, utterance, one verse or take several verses etc., for example, in E. Kästner's poetic text "Der Streichholzjunge" the refrain is created by two verses:

Streichhölzer! Kaufen Sie Streichhölzer!

Drei Schachteln zwanzig! / < ... /

Streichhölzer! Braune und schwarze Streichhölzer!

Drei Paar zwanzig < ...> (Kr., "Der Streichholzjunge").

We need to specify that some poetic texts of E. Kästner are written in a combination of traditional building and steps. This "is a logical continuation of the form of steps and aims at an even more detailed systematization and emphasizing of metrical and sense connections between the crushed parts of the verse" ", emphasizes poetic speech and meter, makes certain groups of words or parts of a single verse more phrasal, increases pauses, intensifies emotions. As scientists note, "in all cases when we catch a deliberate organization in the graphics, we can talk about the poetic meaning of the graphics, since everything, organized in poetry, is made significant"10. For example, in E. Kästner's poetic text "Belauschte Allegorie" the third verse of the quatrain is divided into three verses, maintaining the impression of a dialogue begun in the previous stanzas of the poetic text:

B. Das mein ich. Die Geometrie ist vernünftig.

Da hilft kein Weinen. Da hilft kein Hauen!

Da hülfe nur eins.

A. Und das wäre?

B. Künftig vielleicht keine Pyramiden mehr bauen (Kr., "Belauschte Allegorie").

Another example is E. Kästner's poetic text "Aus der Deutschen Chronik", where the last verse of the six-row stanza is divided into two verses in order to draw more attention to them:

Tags darauf ging folgende Erklärung

(zu der unterbliebnen Volksverrnehrung)

der Regierung zu. Man las und sah:

"Storch hat sich dies Jahr nicht blicken lassen.

Unterzeichneter kann's auch nicht fassen.

Gruß an Seeger.

Deutsches Volk GmbH” (Kr., "Aus der Deutschen Chronik”).

The most frequent type of the strophic structure in E. Kästner's poetic texts is a quatrain of various types $(50,61 \%)$. In addition, frequent is a

9 Назарець В. Особливості графічної організації вірша. Волинь - Житомирщцина : історико-філологічний збірник з регіональних проблем. Житомир, 2002. № 9. C. $197-200$.

10 Лотман Ю. Анализ поэтического текста. Структура стиха. Ленинград : Просвещение, 1972. 272 с. 
combination of different types of stanzas within a single poetic text $(23,03 \%)$, five-row stanzas are significantly used $(14,85 \%)$ and, to a lesser extent, six-row stanzas $(5,46 \%)$.

By the way, the woven rhyme makes up the vast majority $(49,40 \%)$, although the cross rhyme is also common in $35,76 \%$ of cases, and the adjacent and ring rhyme occur only in 3,94\% of cases accordingly. There are also idle rhymes $(3,33 \%)$ and ternary rhymes $(2,12 \%)$. In addition, in the composition of a woven rhyme, we observe a predominant combination of $n$ amounts of the cross rhyme and $n$ amounts of the ring rhyme $(4,24 \%)$.

We emphasize that E. Kästner's poetic texts are written in the silabotonic system $(100 \%)$, where iambus is frequently used $(20,91 \%)$, mainly five-foot $(12,12 \%)$ and four- foot iambus $(6,37 \%)$. However, poetic texts are written mainly by a combination of meter within one poetic text $(78,79 \%)$, usually by a combination of two $(37,88 \%)$, three $(27,27 \%)$, four $(6,68 \%)$ or five $(5,45 \%)$ types of iambus, which conveys the depth of feelings and fragmentary thoughts of the author.

For example, in E. Kästner's miniature "Eine Mutfrage" each verse has a special verse size - one-foot, six-foot, two-foot and four-foot iambus. In the miniature "Was auch geschieht!" two-, three- and four-foot iambus are combined. This discrepancy in poetic metrics can convey the excitement, emotional state of the author or character, draw the reader's attention to significant verses by the content and meaning, for example, E. Kästner's poetic texts "Frau Großhennig schreibt an ihren Sohn", "Abschied in der Vorstadt" etc. At the same time, a sharp break of the meter can serve as an emotional amplification, a mean of emphasizing one's own opinion and so on, as in the poetic text "Repetition des Gefühls". For example, in the poetic text "Besuch vom Lande" the changeable verse size conveys the noise of Berlin, which is also the personification of the big city and accordingly depicts the noise in each big city.

We should note that the combination concerns mainly two ("Naßer November", "Misanthropologie" etc.), three meters within one poetic text of E. Kästner ("Das Herz im Spiegel", "Eine Feststellung", "Sich selbst zum 40. Geburtstag" etc.), although sometimes four meters ("Poesie rer. pol.", "Eine Spitzenleistung" etc.) or five meters ("Der Streichholzjunge", "Die junge Dame vorm Sarggeschäft", "Le dernier cri” etc.) are used simultaneously, sometimes even in greater quantity and quality ("Brief an ein Brachtexemplar", "Wer hat noch nicht? Wer will noch mal?", "Die Fabel von Schnabels Gabel", "Berlin in Zahlen" etc.).

In addition, in some poetic texts of E. Kästner we observe various variations of meter. These are: a clear schematic arrangement ("Helden!", "Jardin du Luxembourg", "Gruß aus den Bergen", "Höhere Töchter im Gespräch" etc.), interchange ("Der schöpferische Irrtum", "Maskenball im 
Hochgebirge", "Präzision", "Bescheidene Frage", "Der Pechvogel" etc.), gradation ("Monolog eines Blinden", "Trost" etc.), a frame of meters ("Wenn im Turm die Glocken läuten", "Kalenderspruch", "Doppelter Saldo" etc.), a decrease ("Trotz allem", "Die Grenzen des Millionärs", "Es läuten die Glocken", "Der Gegenwart ist Gästebuch" etc.), a sharp decrease or break of the meter ("Monolog mit verteilten Rollen", "Der Herr ohne Gedächtnis", "Mißtrauersvotum", "Tagebuch eines Herzkranken" etc.), mismatch of the meter of only one or more verses for the entire poetic text ("Salto mortale", "Was das Volk begehrt", "Mitleid und Perspektive", "Der letzte Anzug" etc.).

But the discontinuity of thoughts does not violate the meter in E. Kästner's poetic text "Die Hummer marseillaise". At the same time, the author is identified with the character, so the entire poetic text presents the character's speech.

It should be pointed out that some of E. Kästner's poetic texts contain identical stanzas or parts of stanzas, thus they are similar to each other and emphasize the difference between separate verses, i.e. certain thoughts of the author, for example, poetic texts "Das Spielzeuglied", "Le dernier cri", "Die scheintote Prinzessin", "Doppelter Saldo", "Keiner blickt dir hinter das Gesicht (Fassung für Beherzte)", "Keiner blickt dir hinter das Gesicht (Fassung für Kleinmütige)".

We believe that a change in the meter, strophic structure and rhyming confirms the aesthetic principles of the "New Objectivity", conveys the fluidity and fragmentary thoughts of the author or emphasizes the importance of separate thoughts, at the same time it increases the perlocutionary effect.

\section{Speech acts and implicatures in the poetic texts of Erich Kästner}

In this paper we distinguish referential speech acts, which correlate nominative units with the real or imaginary world and belong to a certain illocutionary type ${ }^{11}$.

In poetic texts of E. Kästner's lyrical-poetical discourse we distinguish the following illocutionary types of referential speech acts: assertives, directives, expressives, quesitives, commissives and contactives. All types of referential speech acts are implemented in the lyrical-poetical discourse of the "New Objectivity" at the level of a single utterance (as a micro utterance) and/or at the level of the entire poetic text (as a macro utterance) due to a certain linguistic and stylistic means and in various types of artistic

\footnotetext{
${ }^{11}$ Merilai A. Pragmapoetics as literary philosophy. Interlitteraria. Tartu, 2007. № 12. P. 379-392.
} 
communication (vertical(between the author and the reader) or horizontal (between the characters)).

At the level of utterance assertives are mainly used (86,88 and 64,98\%), but a certain part is occupied by directives $(5,55$ and 8,86\%) and contactives $(6,86$ and $9,28 \%)$. On the other hand, expressives are mostly implicit $(0,56$ and $3,38 \%)$, while commissives are slightly represented $(0,15$ and $0,84 \%)$. We allocate quesitives only in horizontal communication $(12,66 \%)$.

E. Kästner's poetic text "Übers Verallgemeinern" is formed by two assertives (statements) and in addition to aesthetic pleasure, makes the reader think about what exactly this poetic text is about (philosophical reflections on the search for truth) and (not)agree with the author's statement:

Niemals richtig.

Immer wichtig (E. Kästner, "Übers Verallgemeinern").

Directives can be, for example, a part of rhythmical and compositional structure. They may start or end the poetic text:

Rumpf vorwärts beugt! Es will dich einer treten!

Und wenn du dich nicht bückst, trifft er den Bauch.

Du sollst nicht fragen, was die andern täten!

Im übrigen: die andern tun es auch $<\ldots>$

Geh vor den Spiegel! Freu dich an den Farben,

die man dir kunstvoll in die Rippen schlug!

Die Besten waren's, die an Tritten starben. -

Rumpf vorwärts beugt! Genug ist nicht genug! (Kr., "Die Tretmühle");

serve as a refrain:

Geh nur weiter. Bleib nicht stehen.

Kehr nicht um, als sei's zuviel.

Bis ans Ende musst du gehen $<\ldots>$

Sind's Buketts für sanfte Riesen?

Geh nur weiter. Bleib nicht stehn $<\ldots>$

Folge folgsam dem Begleiter.

Bleib nicht stehen. Geh nur weiter.

Denn das Jahr ist dein Gesetz (Kr., "Der Oktober”);

or as anaphoric composition:

Spielt hübsch mit Sand und backt euch Sandgebäck!

Ihr seid so fern und trotzdem in der Nähe,

als ob man über einen Abgrund weg

in einen fremden bunten Garten sähe.

Spielt brav mit Sand und baut euch Illusionen!

Ihr und wir Alten wissen ja Bescheid:

Man darf sie bauen, aber nicht drin wohnen. 
Ach, bleibt so klug, wenn ihr erwachsen seid (Kr., "Die Großeltern haben Besuch");

create a compositional ephiphora:

Nun hebt das Jahr die Sense hoch

und mäht die Sommertage wie ein Bauer.

Wer sät, тиß mähen.

Und wer mäht, muß säen.

Nichts bleibt, mein Herz. Und alles ist von Dauer < ...>

Nichts bleibt, mein Herz. Bals sagt der Tag Gutnacht.

Sternschnuppen fallen dann, silbern und sacht,

ins Irgendwo, wie Tränen ohne Trauer.

Dann wünsche Deinen Wunsch, doch gib gut acht!

Nichts bleibt, mein Herz. Und alles ist von Dauer (Kr., "Der August") etc.

In some cases the author asks a question and gives an answer. We consider such rhetorical questions as a speech act of maintaining contact with the addressee, a subtype of a contactive speech act, and the answer to them as an assertive (statement), like in this example:

Wem zwölf genügen, dem ist nicht zu helfen.

Wie säh er aus, der dreizehnte von zwölfen?

Der Frühling müßte blühn in holden Dolden.

Jasmin und Rosen hätten Sommerfest.

Und Äpfel hingen, mürb und rot und golden, im Herbstgeäst $<\ldots>$ (Kr., "Der Dreizehnte Monat").

As an example of expressives we give an excerpt from the poetic text "Patriotisches Bettgespräch", where due to the speech act outrage, a subtype of expressive, the author expresses disagreement with the result of statistical calculations that only misleads people:

Auftausend Deutschekämenwohl pro Jahr

gerade 19 Komma 04 Kinder.

04! Und so was hält der Mann für wahr! (Kr., "Patriotisches Bettgespräch").

An example of the quesitivespeech act is E. Kästner's poetic text "Als die Synagogen brannten" where the speech act a problematic question, a subtype of a quesitive, reflects a wish of the addresser to know the answers to his questions, the addressee does not know:

\section{Der junge SA-Mann:}

Wo steckt Jehova nun, der nie verzeiht?

Ist er, Adresse unbekannt, verzogen?

Der alte Jude:

Gibt's einen Gott, gibt's auch Gerechtigkeit.

Wenn's keinen gibt, was braucht es Synagogen?

(horisontal communication, Kr., "Als die Synagogen brannten”). 
At the same time, among the speech acts at the level of the poetic text dominate assertives (92,43\%) (for example, poetic text "Große Zeiten"), although there are directives $(3,33 \%)$ (poetic text "Die dritte von rechts"), expressives (3,03\%) (poetic text "Hotelsolo für eine Männerstimme") and to a lesser extent contactives $(1,21 \%)$ (poetic text "Wieso warum?"). Quesitivs and comissivs are not established.

The most often used speech acts at the level of the poetic text in the lyrical-poetical discourse of E. Kästner are assertives. For example, poetic text "Die Entwicklung der Menschheit" depicts how a person has developed in the course of existence on the planet, starting with life in the forest and ending with life in a big city. The author is of the opinion that people have not changed in their essence, they only change the world around them. E. Kästner, by the way, emphasizes that people, despite scientific and technical progress, still remain the same monkeys:

Einst haben die Kerls auf den Bäumen gehockt,

behaart und mit böser Visage.

Dann hat man sie aus dem Urwald gelockt

und die Welt asphaltiert und aufgestockt,

bis zur dreißigsten Etage.

Da saßen sie nun, den Flöhen entflohn, in zentralgeheizten Räumen.

Da sitzen sie nun am Telefon.

Und es herrscht noch genau derselbe Ton

wie seinerzeit auf den Bäumen.

Sie hören weit. Sie sehen fern.

Sie sind mit dem Weltall in Fühlung.

Sie putzen die Zähne. Sie atmen modern.

Die Erde ist ein gebildeter Stern

mit sehr viel Wasserspülung <...>

So haben sie mit dem Kopf und dem Mund

Den Fortschritt der Menschheit geschaffen.

Doch davon mal abgesehen und

bei Lichte betrachtet sind sie im Grund

noch immer die alten Affen (Kr., "Die Entwicklung der Menschheit").

At the same time, the second largest type of illocutionary speech acts at the level of the entire poetic text is directives. Directive speech act is illustrated by E. Kästner's poetic text "Die zwei Gebote", where the author urges the reader not to forget about death, but also to love life, to live life, no matter what, as if it is one of the commandments, which creates an allusion to the Bible: 
Liebe das Leben, und denk an den Tod!

Tritt, wenn die Stunde da ist, stolz beiseite.

Einmal leben zu müssen,

heißt unser erstes Gebot.

Nur einmal leben zu dürfen,

lautet das zweite (Kr., "Die zwei Gebote").

Expressive speech acts occupy a small part in comparison with speech actsassertives and directives, for example, E. Kästner's poetic text "Abschied in der Vorstadt" conveys the longing of separation from the beloved:

Wenn man fröstelnd unter der Laterne steht, wo man tausend Male mit ihr stand $<\ldots>$

Wenn sie, ängstlich wie ein Kind, ins Dunkel geht, winkt man lautlos mit der Hand.

Denn man weiß: man winkt das letzte Mal.

Und an ihrem Gange sieht man, daß sie weint.

War die Straße stets so grau und stets so kahl?

Ach, es fehlt bloß, daß der Vollmond scheint $<\ldots>$

Plötzlich denkt man an das Abendbrot

und empfindet dies als gänzlich deplaciert.

Ihre Mutter hat zwei Jahre lang gedroht.

Heute folgt sie nun. Und geht nach Haus. Und friert.

Lust und Trost und Lächeln trägt sie fort.

Und man will sie rufen! Und bleibt stumm.

Und sie geht und wartet auf ein Wort!

Und sie geht und dreht sich nie mehr um <...> (Kr., "Abschied in der Vorstadt").

An example of the implementation of the speech act contactive is E. Kästner's poetic text "Conditio sine qua non", where the poet wants to know how is his beloved, since only then he will know how he feels. This question is an "indispensable condition" for his existence, as already the winged Latin saying in the title hints:

SeufzendschreibtihrderPoet:

"Bist Du heute guter Dinge?

Wenn ich wüßte, wie's Dir ginge,

wüßte ich, wie mir es geht" (Kr., "Conditio sine qua non").

Summing up, we note that the predominance of speech acts assertives at the level of the entire poetic text confirms the superiority of the content of 
poetic text over its form and the main aesthetic features of the movement, in particular factuality and appeal to objective reality.

Implicatures are considered as a component of the meaning of the addressee's utterance, which includes what was meant and what was not said $^{12}$. As you know, G. Grice compared the meaning of what is said (the literal meaning, the meaning of the sentence), and the meaning of what the addressee meant, what he intended to convey to the interlocutor (nonliteral meaning), that is, explicature and implicature, accordingly ${ }^{13}$.

The term trigger ${ }^{14}$ we understand as a speech mean of intending the implicature by the addressee, aimed at activating the implicature in the minds of communicants and it's deduce by the addressee.

The most frequent in poetic texts of the lyrical-poetical discourse of the "New Objectivity" are implicatures, which are performed on the basis of the separate utterances. Triggers of implicatures are linguistic and stylistic means, a variety of their combination and their clarity allows the reader to perform the implicature, at the same time serves as a mean of implementing the author's aesthetic intention, as well as the main aesthetic, linguistic and stylistic features of the poetry of the "New Objectivity". At the same time, a certain mean prevails.

The most common triggers of implicatures in E. Kästner's lyricalpoetical discourse are ambiguity, irony, syntactic parallelism, metaphor, allusion, comparison, types of composition and compositional techniques, but we consider irony, ambiguity, metaphor and comparison to be typical for his idiostyle.

For example, the syntactic parallelism determines not only the melodic and aesthetic expression, but also strengthens the metaphorical implicatures:

Die Erinnrung ist eine mysteriöse

Macht und bildet die Menschen um.

Wer das, was schön war, vergißt, wird böse.

Wer das, was schlimm war, vergißt, wird dumm (Kr., "In memoriam memoriae")

$(+>$ Man soll sich an alles erinnern und nichts vergessen +> ERINNERUNG ist UMBILDUNG).

In addition, in the poetic texts of the lyrical-poetical discourse of the "New Objectivity" we distinguish implicatures based on periphrases, aimed 864 p.

${ }^{12}$ The Handbook of Pragmatics / ed. by L. Horn, G. Ward. Oxford : Blackwell, 2006.

${ }^{3}$ Сусов И. Лингвистическая прагматика. Винница, 2009. 272 с.

14 In: Brown P., Levinson S. Politeness: Some universals in language usage. Cambridge : Cambridge University Press, 1988. XIV, 345 p. ; Clyne M. Transference and triggering: Observations on the language assimilation of postwar German-speaking migrants in Australia. Den Haag : Martinus Nijhoff, 1967. XIX, 149 p. 
at accurately reflecting reality, drawing attention to important facts, events or famous persons, etc., for example:

Den unlösbaren Knoten zu zersäbeln, gehörte zu dem Pensum Alexanders.

Und wie hieß jener, der den Knoten knüpfte?

Den kennt kein Mensch.

(Doch sicher war es jemand anders)

(Kr., "Über den Nachruhm oder Der Gordische Knoten")

$(+>$ Der Gordische Knoten +> Alexander der Große +> Der König Gordios).

The most frequent type of implicature in the lyrical-poetical discourse of the "New Objectivity" is metaphorical, the trigger of which is a metaphor:

Junge Dichter

sind strenge Richter.

Später sind sie dann mitleidiger

und werden Verteidiger (Kr., "Aggregatzustände").

(+> Junge Dichter wollen alles ändern und verbessern wie Richter $+>$ Ältere Dichter verteidigen die Wirklichkeit);

Wir spielen Harfe auf den eignen Nerven (Kr., "Geständnis einiger Dichter")

(+> MENSCH ist HARFE +> Die NERVEN der Menschen sind die SAITEN einer Harfe $+>$ Wir reizen uns selbst).

At the same time, implicatures based on allusion and reminiscence demonstrate a combination with other linguistic and stylistic means, emphasizing the aesthetic appeal of poetic texts, for example, an allusion to Symphony № 9, the last Symphony of L. Van Beethoven:

Dumeine Neunteletzte Sinfonie! (Kr., "Nachtgesang des Kammervirtuosen")

$(+>D u$ (meine Geliebte) bistfürmicheine Sinfonie $+>D u$ bist nur einzige, letzte Geliebte).

The triggers of implicatures in the poetic texts of the lyrical-poetical discourse of the "New Objectivity" at the level of the entire poetic text are both types of composition and compositional techniques, in particular in combination with a variety of linguistic and stylistic means, which increases their expressiveness and perlocutionary effect. For example, the beginning and title of E. Kästner's poetic text "Kennst Du das Land, wo die Kanonen blühn?" is at the same time an allusion to the poetic text "Minion" from the novel by J. von Goethe "Wilhelm Meisters Lehrjahre", a ring composition and partially a refrain, and actualize such a chain of implicatures:

Kennst Du das Land, wo die Kanonen blühn?

Du kennst es nicht? Du wirst es kennenlernen!

(Kr., "Kennst Du das Land, wo die Kanonen blühn?") 
(+> Kennst du das Land, wo die Zitronen blühn? +> Du kennst das Land, wo die Kanonen blühen +> Dieses Land ist Deutschland +> Deutschland ist militarisiert).

In many cases we observe a combination of various linguistic and stylistic means that perform implicatures.

In particular, in the poetic text of E. Kästner "Happy end, d.h. Ende gut" the implicature is based on periphrasis and rhetorical exclamation, as well as on the basis of foreign words, which is indicated in the title of the poetic text and reproduced in the poetic text with the help of antithesis, forming the word play and conveying irony:

Wennzweizum Schlusssichkriegen, sprecht:

Ende gut - alless chlecht! (Kr., "Happy end, d.h. Ende gut").

$(+>$ Das ist gut, dass alles schon zu Ende ist $+>$ Alles am Ende ist schlecht).

The triggers of implicatures on the level of the entire poetic text are any linguistic and stylistic means in different combinations, but frequently is the predominance of a certain mean. In addition, in E. Kästner's poetic text "Das Eisenbahngleichnis" a sense of constant movement, a metaphor of travel, and a metaphorical implicature are created and performed throughout the poetic text through repeats and refrains:

Wir sitzen alle im gleichen Zug

und reisen quer durch die Zeit. $\mid<\ldots>>$

Wir fahren alle im gleichen Zug

und keiner weiß, wie weit. / <... /

Der Zug, der durch die Jahre jagt, / <...> /

Der Zug fährt langsam und hält still. / < ... /

Der Zug fährt weiter, er jagt durch die Zeit,

und keiner weiß, warum. / <... /

Wir reisen alle im gleichen $\mathrm{Zug}$

zur Gegenwart in spe. / <...> /

Wir sitzen alle im gleichen Zug <...> (Kr., "Das Eisenbahngleichnis").

(+> ZUG ist LEBEN +> Das Leben ist eine Reise durch die Zeit +> Keiner weiß, wohin das Leben geht, wie lange es dauern wird, welches Ziel es hat).

So, irony, ambiguity, metaphor and comparison are typical triggers of implicatures in E. Kästner's lyrical-poetical discourse.

\section{CONCLUSIONS}

In conclusion we note that the German-language lyrical-poetical discourse of the "New Objectivity" or "Neue Sachlichkeit" is one of the leading movements of the cultural life in the Weimar Republic and Erich Kästner is one of its representatives. 
Erich Kästner is an unsurpassed master of words and his poetic texts are characterized by fun, cheerfulness, humour, irony and satire, are full of philosophy and aphorisms, as well as biographical features. In the features of Erich Kästner's idiostyle we can find the representation of the author's worldview, personified in language signs and personal manner of writing, which carries perlocutionary effect on the reader.

By the distribution of ideas and themes E. Kästner's poetic texts are mostly civil and philosophical lyrics, but although landscape and urban lyrics.

The rhythmical and compositional structure of poetic texts of E. Kästner's lyrical-poetical discourse demonstrates expressiveness and variety. The author's poetic texts are written mostly without usage of types of composition and compositional techniques, so, the composition of a certain poetic text is determined mainly by the features of the strophic structure. The most frequent are anaphoric composition, refrain, ring of the poetic text and compositional epiphora, as well as a combination of various types of composition and compositional techniques within one poetic text.

The most frequent type of the strophic structure in E. Kästner's poetic texts is a quatrain of various types. In addition, frequent is a combination of different types of stanzas within a poetic text. The woven rhyme makes up the vast majority, although the cross rhyme is also common.

We emphasize that E. Kästner's poetic texts are written in the silabotonic system, where iambus is frequently used. However, poetic texts are written mainly by a combination of meter within one poetic text, which conveys the depth of feelings and fragmentary thoughts of the author.

At the level of utterance assertives are mainly used, but a certain part is occupied by directives and contactives. Expressives are mostly implicit and commissives are slightly represented. We allocate quesitives only in horizontal communication. Among the speech acts at the level of the poetic text dominate assertives, although there are directives, expressives and to a lesser extent contactives.

The typical triggers of implicatures in E. Kästner's lyrical-poetical discourse are irony, ambiguity, metaphor and comparison.

\section{SUMMARY}

The article is dedicated to the investigation of the idiostyle of Erich Kästner, based on his poetic texts. Poetic texts of Erich Kästner are characterized by fun, cheerfulness, humour, irony and satire, are full of philosophy and aphorisms, as well as biographical features, they are mostly civil and philosophical lyrics, but although landscape and urban lyrics. The rhythmical and compositional structure of poetic texts demonstrates expressiveness and variety, because they are written mostly without usage of 
types of composition and compositional techniques, so, the composition of a certain poetic text is determined mainly by the features of the strophic structure. The most frequent are anaphoric composition, refrain, ring of the poetic text and compositional epiphora, as well as a combination of various types of composition and compositional techniques within one poetic text. The most frequent types of the strophic structure in E. Kästner's poetic texts are a quatrain of various types and a combination of different types of stanzas within a single poetic text. The woven rhyme makes up the vast majority, although the cross rhyme is also common. Poetic texts are written mainly by a combination of meter within one poetic text, but iambus is most frequently used. At the level of utterance assertives are mainly used, but a certain part is occupied by directives and contactives; at the level of the poetic text dominate assertives, although there are directives, expressives and to a lesser extent contactives. Irony, ambiguity, metaphor and comparison are typical triggers of implicatures for E. Kästner's idiostyle.

\section{REFERENCES}

1. Бандурко 3. Лінгвопрагматичні властивості німецькомовного лірико-поетичного дискурсу «Нової діловитості» : дис. ... канд. філол. наук: 10.02.04. Херсон, 2019. 325 с.

2. Лотман Ю. Анализ поэтического текста. Структура стиха. Ленинград : Просвещение, 1972. 272 с.

3. Назарець В. Особливості графічної організації вірша. Волинь Житомирщина : історико-філологічний збірник 3 регіональних проблем. Житомир, 2002. № 9. С. 197-200.

4. Парандовский Я. Алхимия слова. Петрарка. Король жизни / сост. и вступ. ст. С. Бэлзы. Пер. с польского. Москва : Правда, 1990. 656 с.

5. Сусов И. Лингвистическая прагматика. Винница, 2009. 272 с.

6. Юріна Ю. Ідіостиль Олени Теліги: дис. ... канд. філол. наук: 10.02.01. Херсон, 2016. 194 c.

7. Brown P., Levinson S. Politeness: Some universals in language usage. Cambridge: Cambridge University Press, 1988. XIV, 345 p. ; Clyne M. Transference and triggering: Observations on the language assimilation of postwar German-speaking migrants in Australia. Den Haag : Martinus Nijhoff, 1967. XIX, 149 p. DOI: 10.1075/itl.2.06van.

8. Gerk A. Lesen als Medizin. Die wundersame Wirkung der Literatur. Berlin : Rogner \& Bernhard, 2015. 317 S. (E-Book).

9. Glaser H. Kleine Kulturgeschichte Deutschlands im 20. Jahrhundert. München : Beck, 2002.398 S.

10. Merilai A. Pragmapoetics as literary philosophy. Interlitteraria. Tartu, 2007. № 12. P. 379-392. 
11. Mörchen H. Vorkriegszeit, Pubertät und Krieg in deutscher Provinz. Ernst Glaesers “Jahrgang 1902" als Roman wider Willen. Neue Sachlichkeit im Roman: neue Interpretationen zum Roman der Weimarer Republik / hrsg. von S. Becker und C. Weiss. Stuttgart, Weimar : Metzler, 1995. S. 112-118.

12. Pankau J. G. Einführung in die Literatur der Neuen Sachlichkeit. Darmstadt : Wissenschaftliche Buchgesellsaft, 2010. 144 S.

13. The Handbook of Pragmatics / ed. by L. Horn, G. Ward. Oxford : Blackwell, 2006. 864 p. DOI: 10.1002/9780470756959.

\section{Information about the author:} Bandurko Z. V., Candidate of Philological Sciences, Lecturer at the Department of Germanic and Romanic Philology Kherson State University 27, University str., Kherson, 73000, Ukraine 